\title{
Pioneers in neurology: Johannes Sayk (1923-2005)
}

\author{
Ekkehardt Kumbier · Uwe K. Zettl
}

Received: 8 July 2009/Revised: 10 August 2009/Accepted: 11 August 2009/Published online: 21 August 2009 (C) Springer-Verlag 2009

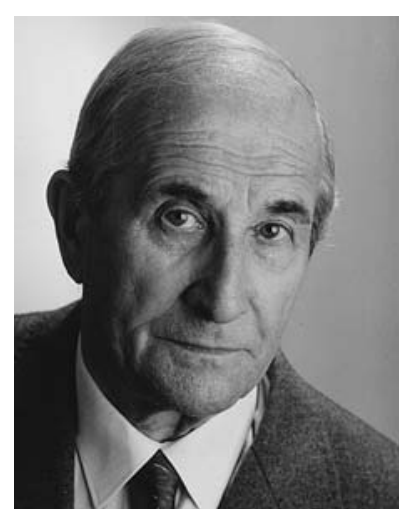

Johannes Sayk was born on 28 September 1923 in Sgonn in East Prussia (today Zgon in Poland) [8]. Upon completing his medical degree in Jena in 1952, he received his neurological-psychiatric training at the University Hospital for Neurology and Psychiatry, directed at the time by Rudolf Lemke (1906-1957), a pupil of Hans Berger (18731941). Following his habilitation (1956) and training at the Brain Research Institute of Oskar and Cécile Vogt in Neustadt (Black Forest), Sayk first became Director of the Neurological Department at the University of Jena, where he was charged with establishing a brain research laboratory. In 1961, at the age of 39, he was appointed to the first independent Chair for Neurology in the former GDR at the

E. Kumbier $(\square)$

Department of Psychiatry and Psychotherapy,

Rostock University, Gehlsheimer Straße 20,

18147 Rostock, Germany

e-mail: ekkehardt.kumbier@medizin.uni-rostock.de

U. K. Zettl

Department of Neurology, Rostock University,

Rostock, Germany
University of Rostock, which he would hold until his retirement in 1989.

At the time of Sayk's move to Rostock, separate psychiatric and neurological chairs had been created only in isolated cases in the former GDR; at the University of Rostock, an independent chair for neurology had been established early on, in 1958 [2]. Sayk turned the clinic into one of the leading facilities in the former GDR. Within a short time, he established an up-to-date clinical neurology service, with appropriate diagnostic facilities. Sayk consistently fostered the development of subspecialist disciplines in neurology and created clinical and scientific working groups, with the central focus on cerebrospinal fluid [5].

Sayk became internationally known by his work on the analysis of CSF. From 1953 onwards, together with ZeissWerk in Jena, he had developed the so-called Zellsedimentierkammer (chamber sedimentation method) [6-8], which was later named after him. Endeavours to develop cytological and chemical procedures for analysis of the CSF had intensified by the middle of the twentieth century [4, 10]. Although Trömner had developed a first sedimentation chamber as early as 1923 , only Sayk's sedimentation procedure allowed a reliable and differentiated assessment of the CSF cells and their reaction forms. Thanks to this method, the cytodiagnosis of CSF received a boost worldwide, for it allowed cells to be concentrated and inspected without damaging them. Sayk's sedimentation procedure was soon to become an indispensable method in CSF examination. Moreover, the distinction of different cell types, given the low cell density in the CSF, offered new diagnostic possibilities. Subsequently, Sayk defined separate CSF syndromes and later also tumour CSF syndromes. His monograph "Cytology of the cerebrospinal fluid", published in 1960, set the trend for many years and became a standard work in this area [6]. His method led to 
numerous further developments. Sayk himself, with Lehmitz, later developed the sorption chamber [3,9].

He successfully formed his own school in Rostock, from which many important studies on CSF emerged. In 1962, a new CSF cytology specialist laboratory had come into being, which became the leading establishment in the former GDR and in which cytological changes in infectious and neoplastic diseases were studied. Furthermore, Sayk and his colleagues examined the CSF changes in the course of multiple sclerosis. Apart from Sayk, his successors, especially Hans-Joachim Meyer Rienecker (born in 1930) and Rose-Marie Olischer (1925-2006), further developed CSF cytology and cytochemical methods, and introduced new directions such as neuroimmunology. Moreover, the Rostock Neurological Clinic developed into a teaching institution for the analysis of CSF, recognised both at home and abroad [4]. Further CSF cytology schools emerged in the 1960s in the GDR in Halle and Jena, all of which were led by Sayk's former colleagues at the Jena Neurological and Psychiatric Hospital [1].

In 1957, Sayk was co-founder of the Research Group of Cerebrospinal Fluid of the World Federation of Neurology (WFN), and in 1963 of the Working Group for Clinical Neurochemistry and Cerebrospinal Fluid Research in the Society for Neurology and Psychiatry of the GDR, out of which the German Society for CSF Diagnostics and Clinical Neurochemistry (Deutsche Gesellschaft für Liquordiagnostik und klinische Neurochemie (DGLN)) arose. In addition to several other awards, Sayk received an honorary doctorate from the Polish Medical Academy Poznan. He was a member of the German Academy of Natural Scientists Leopoldina as well as honorary member of the German Society for Neurology and the Brazilian Academy for Neurology, and he became a Fellow of the Royal
Society of Medicine in Great Britain. Sayk died on 4 December 2005 in Rostock. Today he is seen as a pioneer of cytological CSF diagnostics. However, he also had great merits for the establishment and development of neurology, not only in Rostock but beyond.

\section{References}

1. Kluge H, Wieczorek V, Linke E, Zimmermann K, Witte OW (eds) (2005) Atlas der praktischen Liquorzytologie. Thieme, Stuttgart New York

2. Kumbier E, Haack K, Zettl UK (2009) Fächerdifferenzierung unter sozialistischen Bedingungen - Die Etablierung der Neurologie an der Universität Rostock. Fortschr Neurol Psychiat 77(Suppl. 1):S3-S6

3. Lehmitz R, Sayk J, Kretschmer G (1982) Zellsedimentation mit der Sorptionskammer - Vergleichende liquorzytologische Untersuchungen. Zeitschrift fur medizinische Laboratoriumsdiagnostik 22:224-228

4. Meyer-Rienecker H-J (2005) Geschichte der Liquordiagnostik. In: Zettl UK, Lehmitz R, Mix E (eds) Klinische Liquordiagnostik. de Gruyter, Berlin New York, pp 1-20

5. Meyer-Rienecker H-J (1983) Zur Entwicklung der Neurologischen Abteilung in Rostock - Ein Beitrag zur Spezialisierung des Fachgebietes Neurologie. Psychiatrie, Neurologie, und medizinische Psychologie 35:513-523

6. Sayk J (1960) Cytologie der Cerebrospinalflüssigkeit. Fischer, Jena

7. Sayk J (1954) Ergebnisse neuer liquor-cytologischer Untersuchungen mit dem Sedimentierkammer-Verfahren. Arztliche Wochenschrift 9:1042-1046

8. Sayk J (2003) Von den Masurischen Seen über Königsberg nach Jena und Rostock. Ingo Koch Verlag, Rostock

9. Sayk J, Lehmitz R (1979) Die Sorptionskammer. Eine neue Methode der spontanen Zellsedimentation Das Deutsche Gesundheitswesen 34:2561-2565

10. Schmidt RM (1978) Cytological Atlas of Cerebrospinal Fluid. Barth, Leipzig 